\title{
Sexuality Education Services Needs of Adolescents in Enugu State
}

\author{
Odo, A.N \\ Samuel, E.S \\ Department of Health and Physical Education,University of Nigeria, Nsukka-Nigeria
}

\section{Doi:10.5901/mjss.2014.v5n26p59}

\begin{abstract}
The study determined the sexuality education services needs of adolescents in Enugu State, Nigeria. Three specific objectives, three research questions and two hypotheses guided the study. The study adopted descriptive survey research design. The population of the study consisted all adolescents in Enugu State. The multistage sampling procedure was employed to select 400 adolescents used for the study. Researchers' structured questionnaire was used for data collection. Data generated were analyzed using means scores. The null hypothesis one was tested using t-Test while hypothesis two was tested using ANOVA. The two hypotheses were tested at .05 level of significance. The results showed that sexuality education services are very important needs of adolescents, sexuality education services needs of adolescents did not differ based on gender, but differed based on level of education. Based on these findings, the researchers recommended among others that sexuality education should be made youth-friendly and introduced as a separate subject or course in all levels of education taking age range of pupils into consideration.
\end{abstract}

Keywords: Sexuality, Education, Services, Needs, Adolescents

\section{Introduction}

Maturation from childhood through adolescence to adulthood requires adequate information and services that will enable the young ones face life challenges including that of sexual and reproductive health. The changes that characterize adolescence period are stressful and somewhat problematic to the adolescents. United Nations Population Fund-UNFPA (2010) stated that few young people receive adequate preparation for their sexual lives which leaves them potentially vulnerable to coercion, abuse and exploitation, unintended pregnancy and sexually transmitted infections (STIs), and HIV and AIDS. The agency further stated that many young people approach adulthood faced with conflicting and confusing messages about sexuality and gender, and is often exacerbated by embarrassment, silence and disapproval of open discussion of sexual matters by adults, including parents and teachers, at the time when it is most needed.

Sexuality education is paramount to the promotion of sexual maturation, responsible and safe sex practices among adolescents. Samuel (2010) opined that sexuality education is the process of acquiring information and forming attitudes, skills and beliefs about sex; sexual identity and sexual behaviours with the main purpose of replacing ignorance, fear, secrecy and guilt with authentic knowledge, understanding, openness and rationality. This is mainly because they are sexually active at this early stage of life and if not well educated may fall victims of reproductive health problems. Kolawole (2011) also opined that sexuality education refers to the individual's ability to establish and develop healthy sexual behaviours which enables him to make responsible decisions concerning the physical, emotional and social aspect of personal sexual health. This implies that sexuality education is a broad scope of skills and concepts concerning information about sexual development, reproductive health, interpersonal relationships, and the formation of positive attitudes, beliefs and values as well as development of skills to cope with the biological, psychological, socio-cultural and spiritual aspects of human sexuality.

Information on sexual maturation, healthy sexual behaviours, attitudes, skills and beliefs about sex will definitely promote both the reproductive health and emotional health of adolescents. Federal Ministry of Health - FMOH (2004) posited that quite often, adolescents take emotional risks as well as risks related to pregnancy and STIs, and HIV and AIDS. Most often, subject to peer pressure and influence, adolescents engage in indiscriminate sexual activities. It is, therefore, pertinent to inform and educate adolescents on their sexuality and the need for them to safeguard it through healthy sexual behaviours.

Behaviour change and practice of safe sex should be encouraged. Safe sex includes sexual practices that limit the risk of transmitting or acquiring infectious disease through exchange of semen, blood and other bodily fluids, such as the 
use of condom and avoidance of anal intercourse. Other safe sex behaviours that one can adopt include: abstinence; reduced number of sexual partners to one; not re-using condoms, cervical caps and diaphragms; and avoidance of oral sex. Adolescents, especially females, should know their reproductive rights and protect them. Appropriate sexuality education service provision will help adolescents achieve healthy sexual maturation through adolescence to adulthood. Abubakar and Abubakar (2011) opined that sexuality education services can make a difference by helping young people become sexually responsible, enabling them to form satisfying relationships, helping them to assess their own attitudes toward sex, and giving them information on sexuality. UNFPA (2010) stated that evidence has shown that comprehensive sexuality education that is age-appropriate, gender-sensitive and life skills-based can provide young people with the knowledge, skills, and efficacy to make informed decisions about their sexuality and lifestyle. This implies that adolescents need comprehensive sexuality education services in order to adequately equip them for healthy sexual life.

Need refers to a condition that required relief. Farlex (2014) opined that need is a condition or situation in which something is required or wanted. It is a motivating force that compels action for its satisfaction. Sexuality education service is one of the reproductive health services that require action for its adequate provision. FMOH (2001) stated that the reproductive health needs of adolescents include among others adolescent's sexuality education, antenatal care, safe delivery, postnatal care, and family planning information and services needs.

Adolescents are young people in-between childhood and adulthood. Adolescents according to WHO (2003) are young people between the ages of 10 and 19 years. Onuzulike (2007) defined adolescent as a boy or girl in the process of developing from child to adult. The problem is that this group of people goes through developmental changes that expose them to unhealthy behaviours which often predispose them to sexual and reproductive health problems. Moreover most of the adolescents get wrong or misleading information from their peers or friends. Adolescents, therefore, need adequate and comprehensive sexuality education services, to enable them prevent sexual and health problems.

\section{Purpose of the Study}

The purpose of this study was to determine the sexuality education service needs of adolescents in Enugu State. Specifically, the study determined the:

1. sexuality education service needs of adolescents in Enugu State;

2. sexuality education service needs of adolescents based on gender; and

3. sexuality education service needs of adolescents based on level of education.

\section{Research Questions}

- What are the sexuality education service needs of adolescents in Enugu State?

- What are the sexuality education service needs of adolescents based on gender?

- What are the sexuality education services needs of adolescents based on level of education?

\section{Hypotheses}

- There is no significant difference in the sexuality education service needs of adolescents based on gender

- There is no significant difference in the sexuality education service needs of adolescents based on level of education.

\section{Methods}

The study adopted descriptive survey research design. The population for the study consisted of 1, 124, 842 adolescents in Enugu State (National Population Commission, 2006). The sample for the study consisted of 400 adolescents using Taro Yamane Formular $\left(n=17^{\frac{N}{N}}(e)^{2}\right)$ for sample size (Uzoagulu, 2011). Where $n=$ the sample size; $N=$ the population; $1=$ unit (a constant); and e = level of significance. The multistage sampling procedure was used to arrive at this sample size. First stage involved selecting ten Local Government Areas (LGAs) out of the seventeen LGAs using simple random sampling technique of balloting without replacement. The second stage involved using systematic sampling technique to select four communities each from the ten LGAs that was selected. This gave a total of forty communities. The third sage involved using systematic sampling technique to select ten adolescents from each community. This gave a total of four hundred adolescents, which constituted the sample for the study. 
The instrument for the data collection was researchers' structured Sexuality Education Services Needs Questionnaire (SESNQ). The instrument was divided into two sections, A and B. Section A contained two demographic variables and section $B$ contained items on sexuality education services needs. The instrument was validated by five experts from the Department of Health and Physical Education, University of Nigeria, Nsukka. These experts were requested to determine the credibility of the instrument in achieving the specific objectives. Their suggestions were used to improve on the instrument. Split - half method using Cronbach Alpha statistics was used to establish the internal consistency of the instrument. The validated instrument was administered by the researcher and research assistants on face to face basis of the respondents. Three hundred and eighty-one well completed copies of the questionnaires were retrieved from the respondents. Data collected were analyzed using means and standard deviations. A criterion mean of 2.50 was adopted by adding up the scores assigned to the response options and dividing the sum by the number of the responses $\left(\frac{4+3+2+1}{4}=10 / 4=2.50\right.$ ). All mean scores of 2.50 and above therefore, indicated a sexuality education need, while those with mean score below 2.50 indicated not a sexuality education service need. Mean scores of 2.50-3.49 indicated "important needs" while mean scores of 3.50 and above indicated "very important needs" The t-Test was used to test hypothesis one, while ANOVA was used to test hypothesis two. The two hypotheses were tested at .05 level of significance and appropriate degrees of freedom.

\section{Results}

Table 1: Mean Score Rating of the Sexuality Education Services Needs of Adolescents ( $N=381)$

\begin{tabular}{lllll}
\hline S/N & Items & $\bar{X}$ & SD & Decision \\
\hline 1 & Education on human growth and development & 3.59 & .581 & Very important \\
\hline 2 & Facts and information on puberty and menstrual hygiene & 3.50 & .679 & Very important \\
\hline 3 & $\begin{array}{l}\text { Skills to overcome sexual desires e.g. negotiation skills to } \\
\text { make right decisions and healthy relationship }\end{array}$ & 3.70 & .549 & Very important \\
\hline 4 & Skills to say 'NO' to peer pressure & 3.60 & .648 & Very important \\
\hline 5 & Information on dangers of premarital sex & 3.70 & .636 & Very important \\
\hline 6 & Individual's guidance and counseling on reproductive health issues & 3.48 & .670 & Very important \\
\hline & Gender Means & 3.60 & .640 & Very important \\
\hline
\end{tabular}

Data in Table 1 show that the grand mean score of 3.60 on sexuality education services needs is above the criterion mean score of 2.50, indicating that the listed sexuality education services are needs of adolescents. The table further shows that the mean scores for the items: education on human growth and development (3.59), facts and information on puberty and menstrual hygiene practices through posters, flyers etc. (3.50), skills to overcome sexual desires e.g. negotiation skills, skills to make right decisions and healthy relationship (3.70), skills to say 'NO' to peer pressure and information on dangers of premarital sex (3.60) were indicated as very important sexuality education services needs while individuals' guidance and counseling on reproductive health issues (3.48) was an important sexuality education services need of adolescents. The table also shows that the standard deviations range from .549 to .679. This implies that the responses of the respondents are not too far from one another.

Table 2: Mean Score Rating of Sexuality Education Services Need Based on Gender ( $N=381)$

\begin{tabular}{|c|c|c|c|c|}
\hline S/N Items & Males & & Female & \\
\hline & $\overline{\bar{X}}$ SD & Decision & $\bar{X} \quad$ SD & Decision \\
\hline 1 Education on human growth and development & 3.49 .657 & Important & $3.64 \quad .536$ & Very important \\
\hline $\begin{array}{l}\text { Facts and information on puberty and menstrual hygiene } \\
\text { practices through posters, flyers etc }\end{array}$ & 3.41 .722 & Important & 3.55 .654 & Very important \\
\hline 3 Skills to overcome sexual desires e.g. negotiation skills & $3.67 \quad .536$ & Very important & 3.71 .557 & Very important \\
\hline 4 Skills to say 'NO' to peer pressure & 3.51 .682 & Very important & 3.64 .629 & Very important \\
\hline 5 Information on dangers of premarital sex & 3.66 .675 & Very important & 3.72 .616 & Very important \\
\hline 6 Individuals guidance and counseling & 3.59 .667 & Very important & 3.43 .772 & Important \\
\hline Grand $\bar{X}$ & $3.56 \quad 658$ & Very important & 3.62 .627 & Very important \\
\hline
\end{tabular}

Data in Table 2 show that the grand mean score for female adolescents (3.62) is slightly higher than that of male 
adolescents (3.56), though both are greater than the criterion mean score of 2.50 . This indicates that sexuality education services are very important need for both male and female gender. The table further reveals that very important sexuality education services for both male and female adolescents include; skills to overcome sexual desires (females $=3.71>$ male $=3.67$ ), skills to say 'NO' to peer pressure (females $=3.64>$ males $=3.51$ ), and information on dangers of premarital sex (females $=3.72>$ males $=3.66$ ). However, for items: education on human growth and development (females $=3.64>$ males $=3.49$ ), facts and information on puberty and menstrual hygiene practices (females $=3.55>$ males $=3.41$ ), adolescents indicate that they are very important services needs for females and important services needs for males, while individual's guidance and counseling on reproductive health issues (males $=3.59>$ females $=3.43$ ) is indicated as a very important sexuality education services need for males adolescents and an important need for female adolescents. The table also shows that the standard deviations for male respondents range from .536 to .722 , while those of female adolescents range from .536 to .772 . These imply that the responses of both the male and female respondents are not close to one another.

Table 3: Mean score Rating of the Sexuality Education Services Needs of Adolescents based on Level of Education ( $N=$ 381)

\begin{tabular}{|c|c|c|c|c|c|c|}
\hline \multirow[t]{2}{*}{ S/N Items } & \multicolumn{2}{|c|}{$\begin{array}{l}\text { Primary Education } \\
\qquad(\mathrm{n}=2)\end{array}$} & \multicolumn{2}{|c|}{$\begin{array}{l}\text { Secondary Education } \\
(n=199)\end{array}$} & \multicolumn{2}{|c|}{ Tertiary Education } \\
\hline & $\overline{\bar{X}} \quad \mathrm{SD}$ & Decision & $\bar{X}$ SD & Decision & $\overline{\bar{x}} \quad \mathrm{SD}$ & Decision \\
\hline 1 Education on human growth and development & 4.00 .000 & $\begin{array}{c}\text { Very } \\
\text { important }\end{array}$ & 3.61 .489 & $\begin{array}{c}\text { Very } \\
\text { important }\end{array}$ & 3.57 .620 & $\begin{array}{c}\text { Very } \\
\text { important }\end{array}$ \\
\hline $\begin{array}{l}\begin{array}{l}\text { Facts and information on puberty and menstrual } \\
\text { hygiene practices through posters and flyers }\end{array}\end{array}$ & 4.00 .000 & $\begin{array}{c}\text { Very } \\
\text { important }\end{array}$ & 3.54 .608 & $\begin{array}{c}\text { Very } \\
\text { important }\end{array}$ & 3.48 .711 & Important \\
\hline 3 Skills to overcome desires e.g. sex negotiation skills & 4.00 .000 & $\begin{array}{c}\text { Very } \\
\text { important }\end{array}$ & 3.60 .601 & $\begin{array}{c}\text { Very } \\
\text { important }\end{array}$ & 3.74 .521 & $\begin{array}{c}\text { Very } \\
\text { important }\end{array}$ \\
\hline 4 Skills to say "NO" to peer pressure & 4.00 .000 & $\begin{array}{c}\text { Very } \\
\text { important }\end{array}$ & 3.48 .699 & Important & 3.65 .620 & $\begin{array}{c}\text { Very } \\
\text { important }\end{array}$ \\
\hline 5 Information on dangers of premarital sex & 4.00 .000 & $\begin{array}{c}\text { Very } \\
\text { important }\end{array}$ & 3.50 .801 & $\begin{array}{c}\text { Very } \\
\text { important } \\
\end{array}$ & 3.79 .523 & $\begin{array}{c}\text { Very } \\
\text { important }\end{array}$ \\
\hline $\begin{array}{cl}6 & \begin{array}{l}\text { Individual's guidance and counseling on reproductive } \\
\text { health issues }\end{array} \\
\end{array}$ & 4.00 .000 & $\begin{array}{c}\text { Very } \\
\text { important }\end{array}$ & 3.24 .841 & Important & 3.59 .672 & $\begin{array}{c}\text { Very } \\
\text { important }\end{array}$ \\
\hline Grand $^{\bar{X}}$ & 4.00 .000 & $\begin{array}{c}\text { Very } \\
\text { important }\end{array}$ & 3.50 .673 & $\begin{array}{c}\text { Very } \\
\text { important }\end{array}$ & 3.59 .672 & $\begin{array}{c}\text { Very } \\
\text { important }\end{array}$ \\
\hline
\end{tabular}

Data in Table 3 show differences in the mean scores of respondents with primary, tertiary and secondary education (4.00 $>3.64>3.50$ ) respectively on the sexuality education services needs of adolescents, with primary education higher than secondary and tertiary, and tertiary higher than secondary education. The grand mean scores are above the criterion mean score of 2.50, indicating that sexuality education services are very important needs of adolescents. The table further reveals that while respondents with primary education regarded all the items; education on human growth and development (4.00); facts and information on puberty and menstrual hygiene practices (4.00); information on dangers of premarital sex (4.00); skills to overcome sexual desires (4.00); skills to say 'NO' to peer pressure (4.00); and individual guidance and counseling on reproductive issues (4.00) as very important sexuality education services needs, respondents with secondary and tertiary education indicated that very important sexuality education services needs include; education on human growth and development (secondary $=3.61>$ tertiary -3.57 ); skills to overcome sexual desires (tertiary $=3.79>$ secondary $=3.60$ ); and information on dangers of premarital sex (tertiary $=3.79>$ secondary $=$ 3.50 ); skills to say 'NO' to peer pressure (tertiary $=3.65>$ secondary $=3.48$ ) and individual guidance and counseling on reproductive health issues (tertiary $=3.59>$ secondary $=3.24$ ) are very important needs for respondents with tertiary education and important needs for respondents with secondary education, while facts and information on puberty and menstrual hygiene practices (secondary $=3.54>$ tertiary 3.48 ) is a very important sexuality education service need for respondents with secondary education and an important need for respondents with tertiary education. The table also shows that the standard deviation for primary, secondary and tertiary education range from .000 to ,841, showing that the responses of the respondents are far apart. 
Table 4: Summary of t-Test Analysis Testing the Null Hypothesis of No Significant Difference in the Sexuality Education Services Needs Based on Gender

\begin{tabular}{cccccccccc}
\hline $\mathbf{S} / \mathbf{N}$ & Items & Gender & $\mathbf{n}$ & $\overline{\boldsymbol{X}}$ & $\mathbf{S D}$ & t-cal & Df & P-value & Decision \\
\hline & Sexuality Education & Male & 123 & 21.33 & 2.40 & & & & \\
\hline & & & & & 1.412 & 379 & .159 & Not significant \\
\hline & Services & Female & 258 & 21.68 & 21.261 & & & & \\
\hline
\end{tabular}

Table 4 shows that the t-cal is 1.412 and the P-value of (1.412) which is greater than .05 level of significance at 379 degrees of freedom. The null hypothesis of no significant difference in the sexuality education services needs of adolescents based on gender is, therefore, accepted, implying that the sexuality education services needs of male and female adolescents are the same.

Table 5: Summary of Analysis of variance Testing the Null Hypothesis of No Significant Difference in the Reproductive Health Needs of Adolescents Based on Level of Education

\begin{tabular}{cccccccc}
\hline S/N & Item & Source of Variance & Sum of Square & Df & Mean Squares & F & P-value \\
\hline & Sexuality education & Between groups & 71,816 & 2 & 35.908 & 6.940 & .001 \\
\hline Services & Within groups & 1955.727 & 378 & 5.17 & & \\
\hline
\end{tabular}

Table 5 shows a P-value of .001 which is less than .05 level of significance at 2 and 378 degrees of freedom. The null hypothesis of no significant difference in the sexuality education services needs of adolescents based on level of education is, therefore, rejected, implying that the sexuality education services needs of adolescents of different levels of education are not the same.

Table 6: Scheffe's Post - HOC Analysis of Group Mean Scores Based on Level of Education on the Sexuality Education Services Needs of Adolescents

\begin{tabular}{ccccc}
\hline Dependent & $(\mathrm{I})$ Level of Education & (F)Level of Education & Mean & P-Value \\
\hline Variable & & & Differences (I - J) & \\
\hline Sexuality & Primary education & Secondary education & 3.034 & .175 \\
\hline Education services & & Tertiary education & 2.1771 & .404 \\
\hline Needs & Secondary education & Primary education & -3.034 & .175 \\
\hline & & Tertiary education & $-.857^{\star}$ & .003 \\
\hline & Tertiary education & Primary education & -2.177 & .404 \\
\hline
\end{tabular}

*The mean difference is significant at .05 level.

Table 6 shows the mean difference from the paired mean comparisons for the three level of education (primary, secondary and tertiary education) on the sexuality education services needs of adolescents with their corresponding Pvalues. From the Scheffe's table, the paired means indicated significant difference between secondary and tertiary levels of education (I). The differences lie in the secondary level of education (I) lie between secondary and tertiary education ( $F$ $=-.857, P=.003)$, while the difference in tertiary level of education $(\mathrm{I})$ lie between tertiary and secondary education $(\mathrm{F}=$ $.857, p=.003)$.

\section{Discussion}

Result in Table 1 revealed that all the items are the sexuality education services needs of adolescents. The finding was not surprising because of the fact that adolescents are faced with developmental challenges including sexual and reproductive health issues, which could be properly handled through comprehensive sexuality education services. This finding supports WHO's (2013) suggestion that in order to prevent unwanted pregnancies and other sexual and reproductive health risk, adolescents require information including comprehensive sexuality education. Kumari, Deepshika, Nikki and Singh (2010) also recommended that there should be increased awareness campaign on adolescents' reproductive health issues, which could be done through sexuality education services at different levels of 
development.

The findings in Table 2 showed that both male and female adolescents indicated that the listed sexuality education services are needs of adolescents. The finding was surprising because of the inherent cultural differences in gender roles and the supposed vulnerability of the adolescent girls to sexual and reproductive health issues. The finding however, disagrees with that of Erulkar, Onoka and Phiri (2005) who found out in their study that girls were more particular about sexual and reproductive health services and more sensitive to where they get these services than boys.

Results in Table 3 revealed that irrespective of the differences in levels of education, sexuality education services were indicated as one of the adolescents' needs. This finding was expected because of the fact that every adolescent, despite educational qualifications, experiences the same developmental changes and is also faced with sexual and other reproductive health challenges, which could be effectively managed with the provision of comprehensive sexuality education services. Level of education can, however, influence one's perception and utilization of sexuality education services, but that does not mean that the services are not needed by the individual.

Results in Table 4 revealed that there was no significant difference in the sexuality education services needs of adolescent based on gender, while Table 5 showed that there was significant difference in the sexuality education services needs of adolescents based on levels of education (primary, secondary and tertiary education). Table 6 revealed that the differences were with tertiary and secondary education. The differences may be due to the fact that education increases ones level of knowledge which invariably affects one's decision. The difference might also be as a result of the fact that adolescents with tertiary and secondary education may have been more exposed to literature or studies related to sexual and reproductive health and adolescents.

\section{Conclusion}

From the findings of the study, the following conclusions were drawn;

1. Sexuality education services are very important needs of adolescents

2. Sexuality education services needs of adolescents did not differ based on gender

3. Sexuality education services needs of adolescents differed based on level of education, specifically between secondary and tertiary education.

\section{Recommendations}

Based on the findings discussions, and conclusions of this study, the researchers made the following recommendations;

1. Sexuality and reproductive health education should be introduced as a subject or course in all levels of education taking age range of pupils into consideration.

2. Sexuality education should be made youth-friendly to enable adolescents communicate freely.

3. Adolescents should be equipped with facts about human sexuality.

\section{References}

Abubakar, A., \& Abubakar, A. A. (2011).Sexuality education among adolescent and how to manage their sexual behaviour.Nigeria Journal of Health Education, 15(1), 77-86.

Erulkar, A.S., Onoka, C.J., \& Phiri, A. (2005).Characteristics of youth-friendly reproductive health services most important to adolescents in Kenya and Zimbabwe.African Journal of Reproductive Health, 9(3) .

Farlex (2014). Need. Retrieved 28th April, 2014 from http://www.thefreedictionary.com/need

FMOH (2001).National reproductive health policy and strategy to achieve quality reproductive and sexual health for all Nigerians. Abuja: $\mathrm{FMOH}$.

FMOH (2004).National family planning/reproductive health protocols. Abuja: FMOH.

Kolawole, A.A. (2011). Strategies for quality and effective teaching of sexuality education in Nigeria secondary schools.Nigerian Journal of Health Education, 15(1), 87 - 94.

Kumara, PI, Deepshika, Nikki, K., \& Singh, B. (2010).An empirical study of reproductive health awareness among adolescent girls of Patna City.Home Science Explore, 2(1), 104

National Population Council (2009).Nigeria demographic and health survey. Calverton: the Autor.

Onuzulike, N.M. (2007). Contemporary health matters. Owerri: Con Publishers.

Samuel, E. S. (2010). Human sexuality and family health education Nsukka: Aro-Orbis Publishing Co. Ltd.

UNFPA (2010).Comprehensive sexuality education.Retrieved $7^{\text {th }}$ May, 2014 from www.unfpa.org/public/home/adolescence.

Uzoagulu, A.E. (2011). Practical guide to writing research projects reports in tertiary institutions. Enugu: Cheston Ltd.

WHO (2003).Adolescent Health. Geneva: WHO 
ISSN 2039-2117 (online) ISSN 2039-9340 (print)
Mediterranean Journal of Social Sciences

MCSER Publishing, Rome-Italy
Vol 5 No 26 November 2014

WHO (2003).Family planning methods.Retrieved $5^{\text {th }}$ May, 2014 from http://www.who.int/bulletin/factsheet. 